\title{
The Strategic Use of Renewables to Achieve Demand-Side Management Impact
}

Nancy Carlisle

Steven Hauser

Thomas Potter

Robert Westby

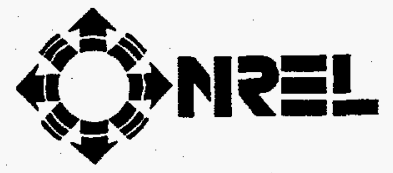

National Renewable Energy Laboratory

(formerly the Solar Energy Research Institute) 1617 Cole Boulevard Golden, Colorado 80401-3393

A Division of Midwest Research Institute Operated for the U.S. Department of Energy under Contract No. DE-AC02-83CH10093

November 1992 


\title{
NOTICE
}

This report was prepared as an account of work sponsored by an agency of the United States government. Neither the United States government nor any agency thereof, nor any of their employees, makes any warranty, express or implied, or assumes any legal liability or responsibility for the accuracy, completeness, or usefulness of any information, apparatus, product, or process disclosed, or represents that its use would not infringe privately owned rights. Reference herein to any specific commercial product, process, or senvice by trade name, trademark, manufacturer, or otherwise does not necessarily constitute or imply its endorsement, recommendation, or favoring by the United States government or any agency thereof. The views and opinions of authors expressed herein do not necessarily state or reflect those of the United States government or any agency thereof.

\author{
Printed in the United States of America \\ Available from: \\ National Technical Information Service \\ U.S. Department of Commerce \\ 5285 Port Royal Road \\ Springfield, VA 22161
}

Price: Microfiche A01

Printed Copy AO2

Codes are used for pricing all publications. The code is determined by the number of pages in the publication. Information pertaining to the pricing codes can be found in the current issue of the following publications which are generally available in most libraries: Energy Research Abstracts (ERA); Government Reports Announcements and Index (GRA and I); Scientific and Technical Abstract Reports (STAR); and publication NTIS-PR-360 available from NTIS at the above address. 


\section{DISCLAIMER}

Portions of this document may be illegible in electronic image products. Images are produced from the best available original document. 


\title{
THE STRATEGIC USE OF RENEWABLES TO ACHIEVE DEMAND-SIDE MANAGEMENT IMPACT
}

\author{
Nancy Carlisle, Steven Hauser, Thomas Potter, Robert Westby \\ National Renewable Energy Laboratory
}

According to both the Electric Power Research Institute (EPRI) and the Edison Electric Institute (EEI), utilities in the United States are now spending about \$2 billion per year on demand-side management (DSM) activities (1). By the year 2000, EPRI and EEI predict that utilities will be spending $\$ 10$ to $\$ 15$ billion per year on DSM (1). If this expenditure is matched by consumers, total expenditures- $\$ 30$ billion a year-will equal what the nation spent on power plant construction during the peak 1970 s power plant building era (1).

Historically, DSM programs at utilities utilize technologies that reduce the demand for electricity and energy used by their customers. This is accomplished primarily by increasing the efficacy of lighting, improving the conversion efficiency of heating, cooling, and process equipment, and reducing thermal losses through the building envelope. A broader definition of DSM-one that incorporates renewable energy resources-will greatly enhance the opportunity to impact customer loads.

Renewable energy technologies use resources that are not depleted, such as heat and light from the sun, the force of winds, falling water, biomass, and geothermal heat from the earth. As related to utility systems, renewable technologies can contribute in three main ways: (1) the more traditional "supply-side" role as central generating plants or independent power producers, (2) as distributed generation (supply-side variation), and (3) as demand-side options. Distributed generation is being seriously studied by several utilities as a means of serving remote loads and reducing transmission and distribution costs. This application will not be discussed further in this paper. Demand-side renewable technologies (DSR) are technologies that utilize renewable energy to reduce the end-use load of a customer (as seen by the utility serving the load).

In this paper we will describe specific DSR options, characterize their potential load impact, and recommend a method for effectively integrating them into current DSM programs.

\section{CURRENT UTILITY DSM PROGRAMS}

Current utility DSM programs are designed to modify customer load shapes in several ways (3) (see Figure 1). Utilities use these programs to alter the shape of the loads they serve to reduce the overall cost of serving these loads. When designed and implemented successfully, costs are reduced for both the customer and the utility. These programs can also add desirable (low-cost, off-peak) loads to the utility and increase overall profitability.

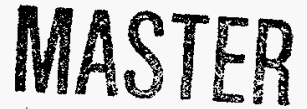


Renewable technologies can be designed to accomplish many of these same load shape changes, resulting in similar benefits to the utility and customer. We will describe below examples of how specific technologies can impact loads. These renewable DSM programs, or DSR programs, have the potential for large impacts while meeting often strict cost criteria. This broader perspective of DSM programs is essential for utilities to make optimal use of available resources while satisfying the changing interest of customers and regulators.

DSR technologies in certain cases may be the most cost-effective option the utility and customer have to provide the needed energy. In addition, DSR offers other advantages that are similar to traditional DSM, such as:

- Incremental growth - DSR technologies are on-site energy sources that can help track uncertain market growth. They allow modular load-matching to reduce peak load growth.

- Transmission and distribution - DSR can reduce utility transmission and distribution requirements for new capacity.

- Market share - Coupling DSR with electric backup can help retain water and space heating load versus natural gas.

- Environmental - DSR can provide a contribution to overall improvements in air quality and can help a utility comply with requirements under the Clean Air Act.

- Public relations benefits - DSR can help offset public concern regarding coal and nuclear power generation and can create good will with consumers, legislators, and regulators.

Many utilities prefer DSM (and similarly DSR) to other options because it not only reduces the cost of power but it also reduces the risk of uncertain fuel prices and environmental costs. Many state public utility commissions now require utilities to explore the least-cost options resulting in large DSM programs. They are also beginning to require utilities, to some extent, to promote 
renewable resources for the "supply side" through competitive bidding programs and specific "set asides." For example, the state of Wisconsin recently established the goal of $811 \mathrm{MW}$ of renewable energy development by 2010 , representing $22 \%$ of new capacity needs (2). However, DSR technologies are not typically considered in these programs.

Current legislation in Congress will provide new production incentives to certain renewable technologies in addition to the continued tax credits for some. If passed this legislation will significantly stimulate the market for renewable generating technologies. However, it is unlikely that DSR technologies would benefit from this legislation as it is currently written.

\section{COMMERCIALLY AVAILABLE DEMAND-SIDE RENEWABLE MEASURES}

Renewable resources are capable of providing heating, cooling, daylighting, and electrical power directly to the customer. The availability of renewable technologies in the marketplace is growing, and the products are reliable. In certain markets the technologies are cost effective, and utilities are using and testing renewables for consideration in their DSM programs. DSR technologies have potential in many parts of the courtry. Contrary to popular thinking, renewables can be cost-effective options in climates as different as California, Iowa, and Vermont.

Certain DSR technologies offer greater near-term potential than others because of their current availability and cost effectiveness. They include:

- Ground-source heat pumps

- Daylighting for new and existing commercial buildings

- Solar water heating

- Passive solar/suntempered building design for new residential buildings

- Dispersed photovoltaics.

Several other renewable technologies may be applicable to smaller residential and commercial markets, including solar pool heating, solar water heating, and passive solar design retrofits. For industrial DSM, solar industrial process heating and solar preheat of ventilation air are renewable options. This paper will focus on the first measures listed.

\section{Ground-source Heat Pumps}

The earth is a massive collector that absorbs and stores heat from the sun. In most climates the ground is warmer than air temperature during the winter and cooler than the air temperature in the summer. Ground-source heat pumps use the earth or groundwater for heating during the winter, cooling during the summer, and supplying hot-water throughout the year. Ground-source heat pumps, as compared to air-source heat pumps, are more efficient and provide better 
performance because the heat source is nearly a constant temperature all year. With proper sizing, no back-up heating is required. The average cost for a ground-source heat pump is in the range of $\$ 2000-\$ 2500 /$ ton of capacity, excluding duct work. The cost varies throughout the country. A typical size is about $3 \frac{1}{2}$ tons.

Ground-source heat pumps can reduce summer peak loads by $1-2 \mathrm{~kW}$ and winter loads by 4-8 $\mathrm{kW}$ for a typical home. More than 100,000 ground-source heat pumps have been installed in U.S. homes to date. They can be installed virtually everywhere in the United States and are especially attractive across a broad band of mid-America in which significant heating and cooling loads exist. They are currently the subject of widespread utility interest, resulting in an industry growth of $10-20 \%$ per year.

According to the University of Utah Research Institute's Earth Science Laboratory (4) there are an estimated 25 million homes in the United States that have central air conditioning without access to natural gas. Replacement of these units alone over the next several decades would save 24,000 to $48,000 \mathrm{MW}_{\mathrm{e}}$ in peak summer demand and 48,000 to $96,000 \mathrm{MW}_{\mathrm{e}}$ in peak winter demand. Over a dozen U.S. investor-owned utilities and many rural cooperative utilities are actively promoting the use of ground-source heat pumps for residential applications.

\section{Davlighting for New and Existing Commercial Buildings}

Daylighting is the intentional use of light entering a space through windows or skylights to reduce the artificial lighting load required to provide specific visual conditions and improve the quality of light in the space. Daylighting technology has been demonstrated in up to 2000 commercial and industrial buildings built in the U.S. between 1974 and 1984 (5). An effective daylighting system generates less heat per lumen of light output than electric lighting. An important advantage of daylighting, from the DSM perspective, is that the greatest available light occurs in the summer. Reducing artificial interior lighting results in less waste heat, reducing the cooling load of the building. Every four $\mathrm{kW}$ of reduced artificial lighting results in $1 \mathrm{~kW}$ in air-conditioning requirements.

It is estimated that adding skylights to seven percent of the roof area in a one-story building will reduce electric lighting use, total electric use, and peak electric demand by 84,40 and $24 \%$ respectively (5).

Based on a study of approximately 20 "climate-responsive" buildings that were built and monitored under a DOE-sponsored program, daylighting reduced lighting energy use in these buildings by $55 \%$ with commensurate reductions in cooling loads often occurring during the afternoon peak in electricity consumption. The daylighting was done with no increase in first cost (6).

Although energy-efficient retrofits with light shelves and aperture controls have been shown to be workable, utilities have found that it is more cost-effective to create energy-efficient buildings during the design phase, and therefore are targeting a greater percentage of their DSM budgets specifically for the new construction market. Reference 7 identifies 35 utilities that are currently operating commercial new construction programs in 1991. These programs recognize the 
complexity of the new construction process and offer technical assistance to design teams. Computerized energy simulations used as a part of these programs show architects and engineers how new construction designs can benefit from a number of conservation and solar design strategies that generally include daylighting.

\section{$\underline{\text { Solar Water Heating }}$}

A solar water heater can be designed to operate in nearly any climate. The performance of the system varies based on the amount of insolation incident on the collectors and the outdoor temperature. In most parts of the country, a solar system is designed to meet $100 \%$ of a home's water heating requirements in summer months. In winter months the system may only meet half of a home's water heating requirements. Therefore, a backup water heater or heating element is necessary to supplement the solar system in winter months.

Solar systems that supply $60 \%$ to $80 \%$ of a household's yearly water heating requirements cost in the range of $\$ 2000$ to $\$ 4000$ (installed).

Figure 2 presents the results of three studies that assessed the influence of residential solar water heaters on electric utility peak demand. The studies are all described in reference 8 . In all three of these studies, the greatest coincident demand reduction, which equalled approximately $0.4 \mathrm{~kW}$ in two studies and $0.7 \mathrm{~kW}$ in the third, occurred in the winter. This is because residential hot water use is a strong component of the early morning winter peak, but it is not as critical during the summer peak period, which is typically in the afternoon. Solar water heating for commercial end-uses will have a much greater impact on summer peak electricity demand.

Figure 3 compares data from 15 homes that use solar water heating (with electric auxiliary heat) with 15 homes that use conventional electric water heaters. Energy savings are realized roughly equally throughout the year, although the percentage of savings in the summer is much greater.

A fourth study demonstrated the impact of a solar water heater programmed for multistaged off-peak charging to provide a $0.86 \mathrm{~kW}$ net capacity displacement during a 16 -hour period on a winter peak day in a cold climate.

A handful of utilities including the Sacramento Municipal Utility District, the Santa Clara Municipal Utility, the Eugene (Oregon) Electric and Water Board, Pacific Power, and Central Vermont Public Service are now offering some type of solar water heating programs.

\section{Passive Solar Design for Residential Buildings}

To date over 200,00 passive solar residences have been designed and built in the U.S. Heating applications use windows to collect heat and interior thermal mass to store heat. The building envelope is well insulated to prevent heat loss. Cooling applications include shading to reduce solar gain, the use of natural ventilation, and earth contact to take advantage of natural cooling available from constant ground temperatures. 


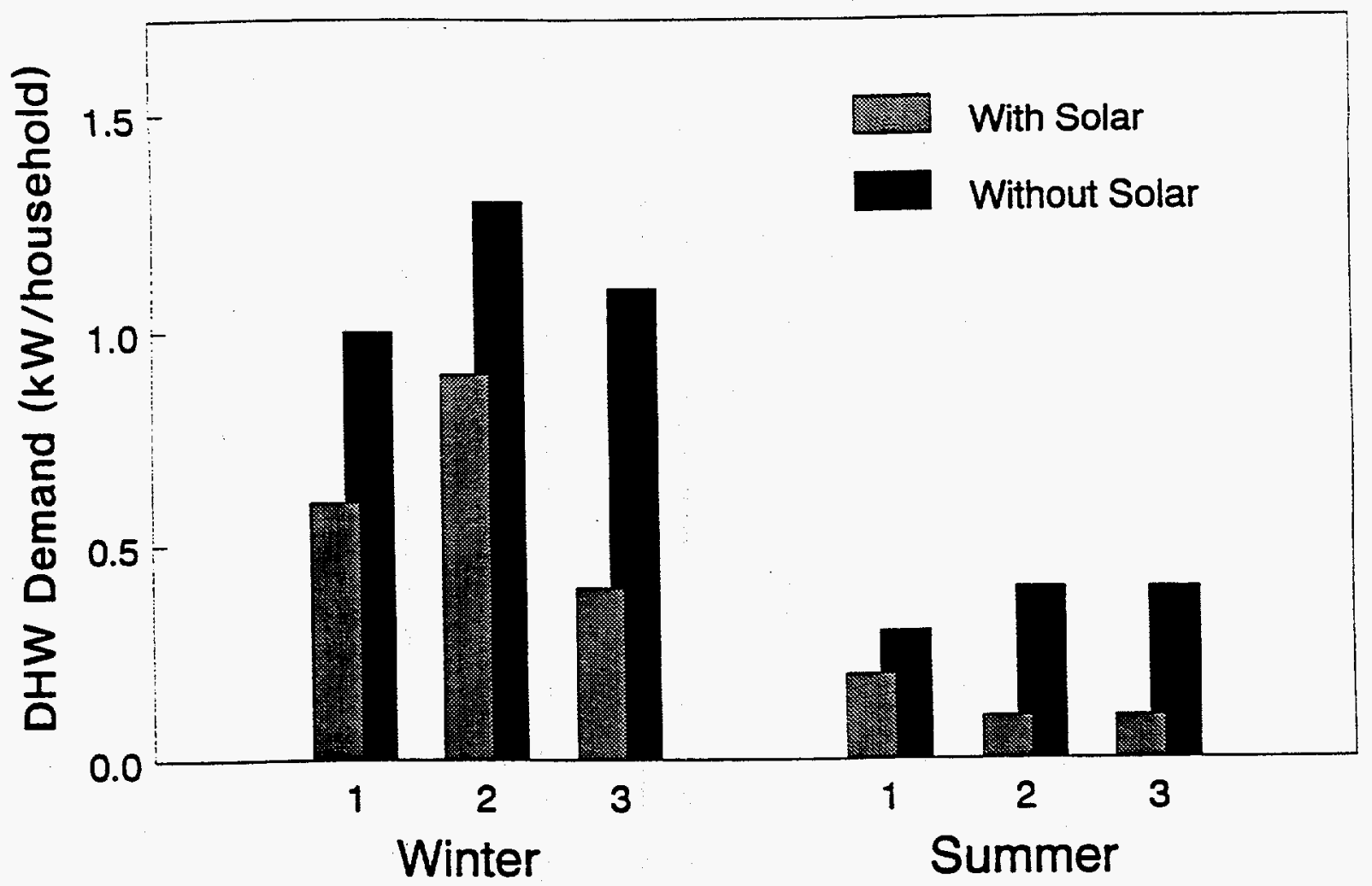

Figure 2. Coincident diversified demand impact of residential solar DHW systems on electric utilities. (Study 1 was conducted in North Carolina with a sample of 55 electric and 24 solar customers; Study 2 was conducted in Texas with a sample of 15 electric and 15 solar customers; Study 3 was conducted in Florida with a sample of 19 electric and 19 solar customers.)

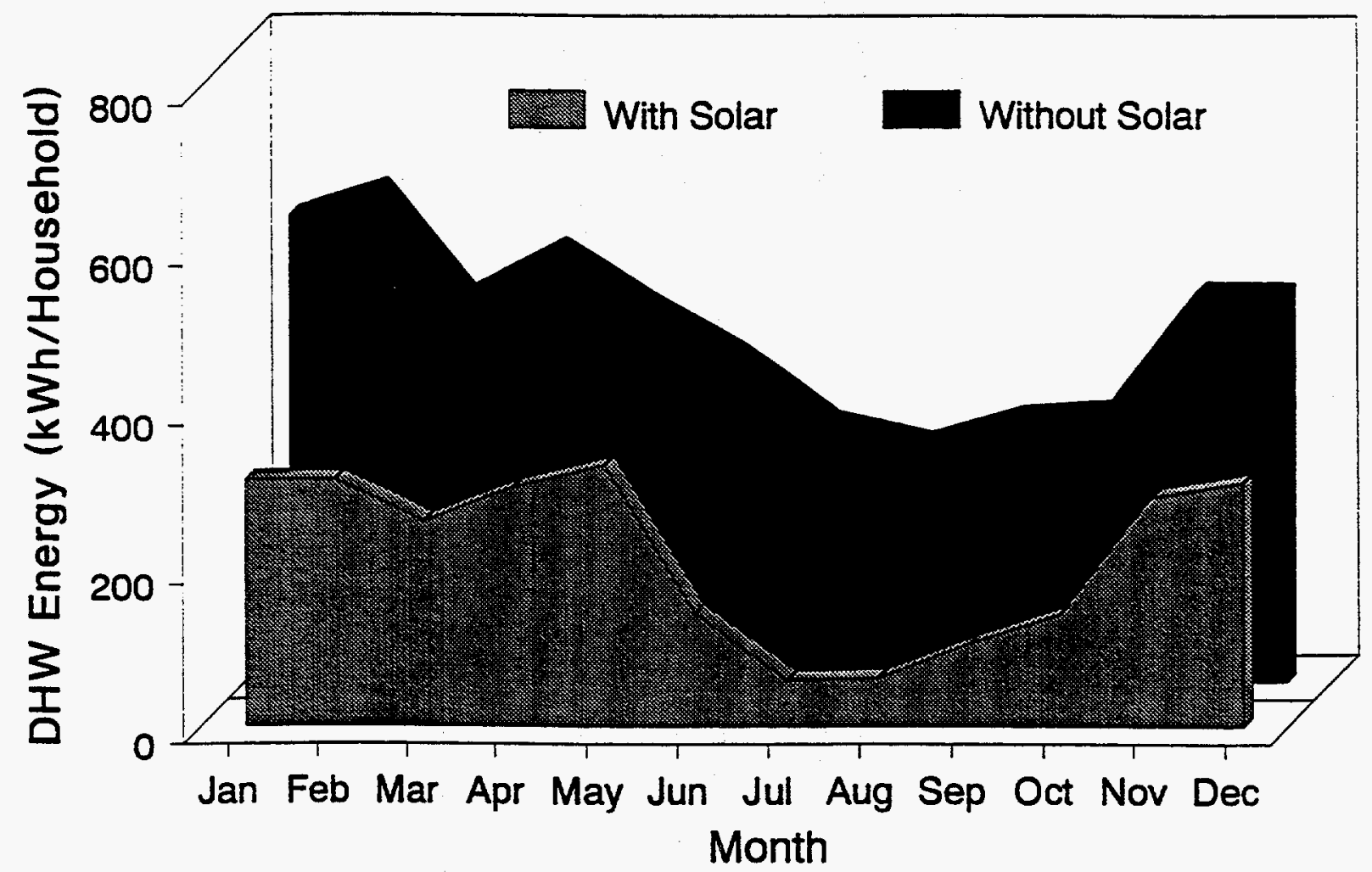

Figure 3. Energy savings from residential solar DHW systems in Austin, Texas. 
Homes built and monitored in the early 1980 s that incorporated passive solar design features had, on average, $40 \%$ of their heating needs met by the sun. Since that time, advanced glazing products and insulation systems have entered the market place. Using these advanced products and systems, the technology exists to reduce a new building's heating load by approximately $80 \%$ and still maintain a conventional house appearance with little or no additional first cost.

As was the case for commercial buildings, U.S. utilities are beginning to recognize that programs focused on new construction are a popular way for them to capture what is otherwise a "lost opportunity" for gaining energy efficiency over and above current building practices. Reference 7 identified 37 utilities in 1991 that offered DSM programs targeted specifically toward new residential construction. It estimates that utilities spent $6 \%$ of their total DSM budgets on residential new construction programs. By employing passive solar design, and encouraging further no-cost steps such as siting for solar access and natural cooling, utilities can significantly reduce a building's heating and cooling requirements. Several U.S. utilities are developing or implementing DSM programs that promote passive solar residential design.

\section{Dispersed Photovoltaics}

Dispersed photovoltaics (PV) as DSR applys PV-generated electricity locally to a particular end use. Research is ongoing to better integrate PV panels into building structures. The ultimate goal is to develop PV panels that do double duty as building components (e.g., roof shingles, wall panels, or windows).

For residential and commercial applications, a PV system can be used to meet specific end-use electricity demand. When a particular electricity need coincides with the sun's intensity, electrical storage systems are less important. PV systems designed to meet these needs are among the simplest, and, therefore, show promise for specific end-use applications. Examples include PV to fully power certain end uses such as swimming pool pumps or attic fans or to partially power other end uses such as PV-powered air conditioning compressors or PV-powered commercial lighting systems.

PV panels for building applications are not cost effective today. However, PV panels offer the potential for producing power coincident with peak demand in commercial buildings. This opens the door for niche markets where PV panels may be able to compete at or near current prices.

\section{SUMMARY AND RECOMMENDATIONS TO DSM COMMUNITY}

DSR programs will make an important contribution to reducing customer loads that utilities must serve. These technologies offer many of the same attributes as traditional DSM programs including cost effectiveness and wide applicability. DSR and DSM options must be considered in concert for utilities to gain the optimum benefit from both.

To evaluate the use of DSR programs for a particular utility customer class, planners must: 
- Determine local resource availability (i.e., solar or geothermal). Excellent references exist on historical data and data collection methods to establish superior data baselines.

- Examine specific customer loads to determine the resource and loads match. Current profiles developed for the establishment of rate classes are often sufficient to satisfy this need.

- Evaluate various renewable technologies for cost effectiveness. Extensive experience now exists for most DSR measures, and performance warranties can be obtained from vendors for advanced technologies.

- Develop DSR programs in concert with existing DSM programs incorporating the best DSR technologies.

We hope that the DSM community will embrace DSR as an integral part of their thinking, planning, and doing, and we applaud those who already have.

\section{REFERENCES}

1. High Country News (July 1992) Part One. The Electric Revolution, Paonia, Colorado: HCN.

2. NARUC Subcommittee on Renewable Energy, State Renewable Energy News, Volume 1, No. 2, Summer 1992.

3. Adapted Clark W. Gellings, highlights of a speech presented to the 1982 Executive Symposium of EEI Customer Service and Marketing Personnel.

4. Earth Science Laboratory, University of Utah Research Institute (March 1992) Geothermal Energy Report.

5. California Energy Commission, Energy Technology Status Report. June 1991.

6. Burt Hill Kosar and Rittleman Associates and Min Kantrowitz Associates (1987) Commercial Building Design. New York; Van Nostrand Reinhold Company.

7. Wikler, G. and A. Faruqui "The Dynamics of New Construction Programs in the 90s: A Review of North American Experience," Barakat and Chamberlin, Inc. May 1992.

8. N. Carlisle, C. Christensen, L. Barrett (May, 1992) Opportunities for Utility Involvement with Solar Domestic Hot Water. Golden, CO, NREL (NREL/TP-432-4799). 